Jurnal Ilmiah Al-Syir'ah Vol. 18, No. 2 (2020): 91-111

Website: http://journal.iain-manado.ac.id/index.php/JIS

ISSN 2528-0368 (online) ISSN 1693-4202 (print)

\title{
ADMINISTRATION AND FINANCE SYSTEM OF THE OTTOMAN EMPIRE
}

\author{
Meirison \\ Faculty of Ushuluddin, Universitas Islam Negeri Imam Boniol Padang, West \\ Sumatera, Indonesia, Jl. Prof. Mahmud Yunus Lubuk Lintah, 25153 \\ E-mail: meirison@uinib.ac.id
}

\begin{abstract}
The article aims to reveal the form of administration of the Ottoman Empire, which is not much discussed in history books, especially in Indonesia, an administration that seems chaotic. The description and form of administration take from various sources, especially in the collapse and degradation of leadership. The author tries to explain the advantages and disadvantages of the Timar system run by the Ottoman Turkish Empire. Data collection is carried out through literature study, data verification, interpretation, and financial administration chronology writing. The results show that the Ottoman Empire system of government has developed according to its territoryadministration of agricultural Land managed by Sipahi and Subasyi. In implementing the Ottoman Islamic Sharia, the judges have the task of settling civil, criminal, and financial cases in coordination with the regional government and the government. At a glance, the Ottoman had a feudal system similar to the West's system at the time, but there were fundamental differences in land ownership. Land tenants in the West have no right to enjoy the harvest, let alone control the Land for generations. Slaves in Western Europe cannot be separated from hereditary Land. They cannot enjoy the agricultural products they have worked for themselves the Timar system's dysfunction results in losses in military, economic, social, and educational procurement. Even though, when analyzed in the Timar system, many support food security. However, this system still illustrates the principle of the land system adopted by Islam, namely Land to the tiller.
\end{abstract}

Keywords: Administration; finance; System; Ottoman Empire

How to Cite: Meirison. (2020). Administration And Finance System of the Ottoman Empire. Jurnal Ilmiah Al-Syir'ah, 18(2), 91-111.

Permalink/DOI: http://dx.doi.org/10.30984/jis.v18i2.1113

Copyright (C) 2020, Jurnal Ilmiah Al-Syir'ah

Administration And Finance System of the Ottoman Empire 


\section{Jurnal Ilmiah Al-Syir'ah Vol. 18, No. 2 (2020): 91-111 \\ Website: http://journal.iain-manado.ac.id/index.php/JIS ISSN 2528-0368 (online) ISSN 1693-4202 (print)}

\section{INTRODUCTION}

This article aims to explain writers have not much discussed the Ottoman Turkish government administration and financial system in the country. A country would not stand for a long time without an established administrative and economic policy. The operation of government administration and finance grew based on government and funding of its predecessor, the Bani Seljuq. In the book entitled Daula Iliyah al-Usmaniyah compiled by Muhammad Farid Beik, it was explained that the Ottoman Sultans appointed their representatives to handle regional administration, having the first ranks given the title Beik. Who came from the military who functioned as executive executors. Whereas in Tarikh al-Qada fi alIslam compiled by Muhammad Zuhaili explained the judge who came from among the ulama who held judicial authority, which was also part of the Sultan's duty. Beik cannot enforce the law before there is approval from the judge as the judge cannot execute the code he has decided in court (Halim, 1987). The author finds that the judges decided independently of matters relating to civil law and sharia without consulting with Beik. Because the judge got the mandate directly from the Sultan, all cases and suits can be submitted directly to him. This division is the basis of the administration of the Ottoman government. It is considered standard and has never been changed. In general, the Ottoman Turkish government is related to and is in the corridor of Islamic law based on various sources, such as a book written by Robert Mantran entitled Histoire de L'empire Ottoman. The Ottoman Turkish government is bound by Islamic law in all respects to finance and food security (Mantran \& Bacqué-Grammont, 2003).

Ottoman Empire was considered a sick country, a sick man from Europe who did not have an excellent administrative and financial system even in chaos. The administrative and financial procedures had brought the Empire to ruin. Can an empire that has existed for hundreds of years with a chaotic administrative and economic system? Medieval economies were more focused on agriculture and Land. At first glance, the Ottoman land system was the same as Europe, which used workers and slaves with a feudalism system. The fundamental difference lies in land ownership; Islam's ownership system still applies to the Ottoman Empire. Unlike in Europe, the workers will remain workers until death. Simultaneously, workers in the Ottoman Empire workers could own land and change professions to cities if they had other skills. The economic system in the Ottoman Turkish agricultural sector was called Timar. The Land give to managers who will enjoy the results. In war, the manager must provide soldiers and horses, and other war equipment to join the Ottoman army. The number of soldiers and military logistics provided depends on the Land's size and the yields obtained. The land workers consisted of slaves and ordinary people who could change professions and were not tied to agricultural Land as in Europe. After the Timar System was abolished, the independent Ottoman economy became weak and became one of the destruction factors.

This paper's novelty explains the color of Ottoman Turkish rule dominated by a feudal military government different from Western feudalism. Ottoman land 


\section{Jurnal Ilmiah Al-Syir'ah Vol. 18, No. 2 (2020): 91-111 \\ Website: http://journal.iain-manado.ac.id/index.php/JIS ISSN 2528-0368 (online) ISSN 1693-4202 (print)}

law is influenced by Islamic land policy, manifested by the Hanafiah School's opinions and the local land system's clash. Unlike the Western image that the Ottoman Empire, between terrible enemies and exotic paradise. However, this Empire establishes an orderly system of financial administration closer to humanity and humanizing human beings.

\section{RESEARCH METHODS}

In discussing the problems of regional administration and finance of the Ottoman Empire, the writer conducted a literature study, collecting data, verifying, analyzing, and writing the Ottoman and financial administration's chronology and ending with rewriting the history of the Ottoman Empire and financial administration. The author discusses the descriptive method and analyzes the problems obtained from this literature comparatively. The author explains the content that produces a picture of the Ottoman Turkish government and financial administration system. The author concludes this Timar system has maintained food security for hundreds of years and has fought in economic stability from the data study.

The agricultural commodities, especially staple foods, are circulating in the country. This Timar system prevents agrarian items from being exported abroad. Coupled with the Sultan's policy and supervision of officers who always live in the Timar region, food commodities' circulation is still under surveillance (Mantran \& Bacqué-Grammont, 2003).

\section{RESULTS AND DISCUSSION}

The Ottoman has initially been a small courtroom that was given the task of guarding the border by Sultan Alauddin as-Saljuki, who was named Sancağı Sultan, which meant the Sultan's or Badsyah's aide. Sancağ1 is also used for provinces where Beik Sancağ 1 is a governor. (Saharuddin et al., 2020) Sancağ1 will be inherited from generation to generation without any new appointment from the Sultan unless something happens that demands to be done in the province's leadership structure. Sancağ is an administrative unit led by a military government (Sancağı Beik) given a flag from the Sultan as a symbol of his leadership and power. The Ottoman state experienced very rapid development in the densely populated Balkans in $1361 \mathrm{AD}$, so it was needed to appoint the provincial government coordinator Beklor Beik to control the Balkan situation which included, Bulgaria, Romania, Moldavia, Serbia, Bosnia, and Kosovo (Pamuk, 2010). Sultan Murad, I appointed his loyal teacher as Beklor Beik, so Beik Bekwiyah was established in the Balkans (Aykan \& Ergene, 2019).

After that, Murad I appointed his son to be Bayazid as ruler in the East's new territory. He made Kotahiyah as capital. Beik Bekwiyah (Federal Head of State) while in Amasia led by one of the Amirs. That was the Ottoman empire's administration until the end of the 14th century A.D. consisted of Beik Bekwiyah, who was considered a supporter of the sultanate rules. The Ottoman Forestry

Administration And Finance System of the Ottoman Empire 


\section{Jurnal Ilmiah Al-Syir'ah Vol. 18, No. 2 (2020): 91-111 \\ Website: http://journal.iain-manado.ac.id/index.php/JIS ISSN 2528-0368 (online) ISSN 1693-4202 (print)}

expanded power gradually but inevitably into the Central European region (Khoury, 1996). areas were the administration of several Sancağ under the direct control of the Ottomans and the territories under the power of the Ottoman to be conquered (Dar al-Harbi). In the border areas, the Beiks is freer to play their government role and far from the central government's influence compared to the Beik, whose territory is close to the capital. The Beik system was adopted when Usman bin Ertugrul became the Beik for the Seljuk kingdom formed by the Sipahi (Beik's aides in military service).

Meanwhile, countries under the Ottoman Empire's control and protection are given broad autonomous rights for domestic problems (Pamuk, 2004). These non-Muslim countries pay annual jizyah (levies on non-Muslims in Muslim countries) and provide military personnel complete with war equipment in a war. In some areas, the Sultan's attention was more focused on Beik at the border, such as in Romania, Transylvania, Serbia, Bosnia, and Otranto (Italy) (İslamoğlu-İnan, 2004).

The Ottoman government gave direct control over these territories to Beik Beikwat (leader of the Beiks) In the 5th and 6th centuries A.D. The appearance of this position took 170 years, starting from 1463-1580 AD. In that period, Bosnia had become Beik Beikwat consisting of several provinces combined into a large force. He was done to face Austria, Germany, Poland, the Netherlands, and Spain controlled by the Hapsburg family. Formed Beklor Beik (Beikwiyah) named Ozu, consisting of several Sancağı (several provinces) located in the Black Sea region as a defense to face the Cossacks (countries around Russia) At the end of the 16th century A.D. Thus in the Empire, until it was known in $1520 \mathrm{AD}$, there were only six Heads of Beik (Beik Beikwat). Until the time of Sultan Sulaiman al-Qanuni, the number of Beikwat Beikwat reached sixteen Beikwat Beikwats (İnalcık \& İnalcık, 2014).

In 1533 the Beikwiyah Beik fleet in the face of Charles Quint (Charles V), Spain, Germany, the Netherlands, Austria, and the Americas. The whole area of Algeria is under the control of Hayreddin Barbarossa (the orange beard). Simultaneously, the coast of Libya, Tunis, and other Mediterranean seaside beaches is divided into 13 Sanjak (Khoury, 1996). Barbarossa was given the title AlQubudan Darya (Admiral / Amir al-Bahr). The term Beikwat changed at the end of the 16th century into Iyalat, which was reduced in territory and territory because the Ottoman Empire slowly experienced economic setbacks and a crisis of leadership and pressure from Western countries and Russia. In $1610 \mathrm{AD}$, the Ottoman Empire became 32 Iyalah, according to the schedule on table 1: 
Jurnal Ilmiah Al-Syir'ah Vol. 18, No. 2 (2020): 91-111

Website: http://journal.iain-manado.ac.id/index.php/JIS ISSN 2528-0368 (online) ISSN 1693-4202 (print)

Table 1. Eyalet (Province)

\begin{tabular}{|c|c|c|c|}
\hline $\begin{array}{c}\text { Beik Beikwiyah (Head of } \\
\text { Federal State) }\end{array}$ & Capital & Date of Conquer & Year Built \\
\hline Ar-Rumeli & $\begin{array}{l}\text { Edirne, Sofia (Romania), } \\
\text { Monaster }\end{array}$ & $1361-1385$ & 1362 \\
\hline Anatolia & Ankara, Kotahiyah & $1354-1391$ & 1393 \\
\hline Ar-Rum & Amasia, Siwas & $1392-1397$ & 1413 \\
\hline Tribezone & Trabzon & 1461 & 1578 \\
\hline Bosnia & Sarajevo (Saray Bosna) & 1463 & 1580 \\
\hline Karaman & Konya & $1468-1478$ & $1468-1512$ \\
\hline Kafa & Kafa & $1468-1478$ & 1568 \\
\hline Zulkadir/Dulkadir & Mar'asy/Bustan & 1515 & 1522 \\
\hline \multicolumn{4}{|l|}{ Beyliği Dönemi" } \\
\hline Erzurum & Erzurum & 1514 & 1535 \\
\hline Diyarbakir & Diyar Bakr & 1515 & 1515 \\
\hline Mosul & Mosul (Iraq) & 1516 & 1535 \\
\hline Aleppo & Aleppo & 1516 & 1516 \\
\hline Damaskus & Damask & 1516 & 1517 \\
\hline Tripoli (Syams) & Tripoli & 1516 & 1570 \\
\hline Egypt & Cairo & 1517 & $1517-1522$ \\
\hline Yaman (Aden) & Zubaid dan Sana & $1517-1538$ & 1540 \\
\hline Algeria & Algeria & 1516 & 1533 \\
\hline Qarish & Qarish & 1534 & 1580 \\
\hline Baghdad & Baghdad & 1534 & 1534 \\
\hline Wan & Wan & 1533 & 1533 \\
\hline Tunis & Tunis & 1534 & 1573 \\
\hline Basrah & Basrah & $1538-1546$ & 1546 \\
\hline Al-Ahisa & Al-Qatif & 1550 & 1555 \\
\hline Budin & Buda & $1526-1541$ & 1541 \\
\hline Tripoli Barat (Libya) & Tripoli & 1551 & 1556 \\
\hline Tımışvar & Tımışvar & 1552 & 1552 \\
\hline Sharazur & Sharazur & 1554 & $?$ \\
\hline Habsyah & Sawakin, Jeddah & $1555-1557$ & 1557 \\
\hline Cyprus & Nicosia & 1570 & 1570 \\
\hline Jildir & Jildir & 1578 & 1578 \\
\hline
\end{tabular}

Source: (Inalcik, 1969). 


\section{Jurnal Ilmiah Al-Syir'ah Vol. 18, No. 2 (2020): 91-111 \\ Website: http://journal.iain-manado.ac.id/index.php/JIS ISSN 2528-0368 (online) ISSN 1693-4202 (print)}

The Ottoman government cannot apply Timar Law except in the regions listed above because the Sanjaq system and Ottoman laws apply in these areas. In contrast, in other regions such as Hungary, Serbia, and the Northern Transylvania, the Ottoman government does not change the existing political stability and tax payments system. As long as their trading activities are not contrary to Islam, they will be left as they were before the Ottoman conquest. Whereas in Egypt, Basra, alAhisa, Habsyah (Sudan), Timar law was also not implemented because these regions were given autonomous rights free to determine the government and financial management they would perform. The Sultan only sends a governor and a judge, a financial officer to one of these regions. In these areas, regional income is not distributed to the Sipahi in the form of Timar. The governor regulates military spending by providing daily or monthly salaries to civilian and military personnel, and then the rest is brought to the center in a predetermined amount. The regional income sent to the central government is called Salalaniyah. Therefore these areas are known as the Salaniyah region. This Sancağı region is an inherited area different from the other regions (Meirison Meirison, 2019b). Its leadership was inherited by tribal leaders in many places in East Anatolia and Kurdistan. In this Sancağı region, any proceeds from the regencies claimed to be submitted to Beik inherited this position. The Beik should send cavalry (cavalry) when the Sultan requests him, as the Sultan sends a judge and regiment of elite soldiers (Janissari) to essential cities in the region. Simultaneously, the Salaniyah region did not experience this because Ottoman's rule has granted these regions autonomous rights, such as Walachia, Transilvania, Doubrovenik, Circosia, Cossack, the kingdoms around Cremia (now Russia), the Makkah region. Simultaneously, the North African coastline regions such as Libya, Tunis, and al-Jazair are considered buffer zones that guard the Ottoman border against infiltrating enemy nations (Issawi, 1980).

In the 16th century C.E., the Ottoman government theoretically had sovereignty over Venice, Poland, the Habsburg Empire (Austria and Germany). These great empires paid an annual tribute to the Ottoman Turks. Even France was under the Ottoman Empire's sovereignty when the French king Francais I requested protection from the Ottoman Empire to survive the expansion of Charles Quint, the ruler of Hapsburg (Farid Bek Al-Muhami, 2009). The Ottoman Turkish government applied the Timar system to parts of its regions and provinces because the need for military personnel and equipment procurement was very high. In medieval times this system used in various countries, even in Europe; the land managers were slaves who could not move from the Land they were working on because there was no possibility to free themselves. Even marital problems must ask permission from the employer. If the slaves gave birth to children by themselves, the children would become slaves on the Land, and if the employer sold the property, the slave would still be attached to the ground he was working on and could not move to another place (Taskinsoy, 2019).

The main problem faced by the Near East Empire was the procurement of gold and silver for printing currencies. Countries that cannot procure large amounts of gold and silver will not be able to purchase large numbers of personnel and 


\section{Jurnal Ilmiah Al-Syir'ah Vol. 18, No. 2 (2020): 91-111 \\ Website: http://journal.iain-manado.ac.id/index.php/JIS \\ ISSN 2528-0368 (online) ISSN 1693-4202 (print)}

maintain military equipment for a long time. Whereas farmers cannot pay taxes with gold or silver, they can only pay taxes (al-Ushur) with agricultural products they obtain from their fields. Therefore there is no Hanafi school of law that allows payments to be replaced with money in these areas. They pay their Kharaj (land tax in Islam / Kharaj refers to the land tax levied by Muslim rulers on their non-Muslim subjects, collectively known as dhimmi). Ushr (a 10\% tax on the harvests of irrigated Land and 10\% tax on the harvest from rain-watered Land and 5\% on Land dependent on well water. The term used for a $10 \%$ tax on merchandise imported from states that taxed the Muslims on their products. Caliph 'Umar ibn Al-Khattāb was the first Muslim ruler to levy Ushr) with agricultural products, zakat, or other Kifarat fines (violations of Islamic law) Shafi'i school. Therefore the state sold it to tax collectors, which caused losses and price reductions due to the difficulty of gold and silver at the time. This tax collection is left to military forces, which are collected directly and taken as their salaries. The Byzantine Empire carries it out called Pronoia, which is also named Timar in Persian. This method has been used for a long time (Pamuk, 2004).

Therefore Sipahi, the tax collection forces, are always in the villages so that they are easy to collect agricultural products that will be paid for them and the country. Sipahi is responsible for exchanging agricultural products with gold and silver. The Sipahi military group also manages its horse farms in the villages where they live, which is then used to fight. Farmers in the Byzantium region are required to provide wood-carrying carts, carts for fodder, straw carts. Moreover, farmers were forced to work on agricultural Land owned by landowners. When the Ottoman Empire got into the landlords' habit of conquering the Balkans, changing the Pronoia system to Timar had no difficulty. All Land owned by landlords and Catholic churches was made into Timar (Barkey \& Gavrilis, 2016).

To build the Timar system and carry out intensive supervision and centralized governance, the government must verify each region's income in detail. Every gain and expenditure has records, and audits are conducted periodically by judges and financial officers. The officer determines the source's revenue for the country, picking the budget and development planning and depositing it to the central government. A review of each region's system and financial reports takes place every 20 to 30 years later. Surveys that take into account cumulative tax volumes in each area. They recorded each head of the family's names in the villages and the size of the Land they owned. With these data, they estimated the agricultural output and the amount of tax collected (al-Ushr) called Jafat Rasmi. Fees are contained in the form of currency, while Christians are named Ispanjah. Other taxes also exist, such as the violation tax levied on civil or criminal law violations, but the Hanafi School allows money to be replaced. Besides, there is also a marriage tax because everyone who gets pleasure like a marriage should be taxed. After the calculation is complete, the income is deposited to the state, ministers, and regional heads. The rest of the fixed deposits were given to the cavalry forces in the form of Timar and Za'amat. Za'amat is the annual ration given to Subasyi for 20-100 aces. 


\section{Jurnal Ilmiah Al-Syir'ah Vol. 18, No. 2 (2020): 91-111 \\ Website: http://journal.iain-manado.ac.id/index.php/JIS ISSN 2528-0368 (online) ISSN 1693-4202 (print)}

While the land tax yield of more than 100.000 Akce is called Typical (Inalc1k \& İnalc1k, 2014).

After a cumulative and detailed calculation, this tax allocation is explained (al-Khas, Za'amat, and Timar). On the Muqadimah, the tax record is attached to Qanun-Namah, which sets out the taxes and requirements met by Fursan Sanjaq to collect these taxes. The farmers pay taxes according to these rules until new rules usually change after decades later. If there is a dispute between the tax collectors, the judge will mediate and settle the case. These collected tax records are filed in the financial department conducted by Nisanji, and the regional heads keep other sheets (Inalcik, 1969).

If we look at the ancient Timar system is similar to the feudal system of Medieval Europe. However, if we look closely, we find the underlying differences between Timar and the European Feudal System in the Middle Ages. The state should stretch its absolute legitimacy and authority over individual ownership of Land to implement the Timar system. As was the case in the Daula Islamiyah era, the Ottoman Daula stated that agricultural Land under al-Amiri (under state authority), except private property and endowments, then the government has the right to determine and replace its managers. Following the statement of the Ottoman government, agricultural Land is state property. The farmers who work in the fields and fields work from generation to generation in return for their work are entitled to harvest the Land they manage. Farmers are allowed to land under hereditary management, and they cannot sell the Land except with special permission from the government. Government officials always try to control these lands by expanding personal rights to the property, as the landowner during the Abbasid Caliphate and the Byzantine Empire. During the Ottoman Empire, there was a struggle between private ownership and state ownership, which caused problems throughout history. If the state's power weakens, the capacity for personal property and endowment over the Land will suddenly expand. If a powerful sultan sits in power, he will immediately cancel private ownership and grants, and everything belongs to the state. In this matter, Sultan Bayazid I and Sultan Muhammad al-Fatih improved the standard rules on purchasing the Land (Finkel, 1988).

In $1470 \mathrm{AD}$, when Muhammad al-Fatih reviewed the ownership of agricultural Land in the Ottoman Empire. The Sultan returns the waqf lands that do not yet have permission to become the state's property. The purpose is not following what was previously planned. As a result of this policy, 20,000 villages and fields were returned to the country. From this policy, Sultan Muhammad al-Fatih wanted to increase the number of soldiers by increasing the volume of this agricultural Land, which was guarded and managed by the military, which would be used to expand the region to Western Europe. However, in Anatolia, the Sultan left the land ownership to individuals and dervishes (Naqhsabandi Sufi order) (İnalc1k, 2016). However, Muhammad al-Fatih required that the agricultural landowners provide a cavalry force complete with weapons during the war with the Sultan's orders. During Sultan Bayazid II, a new policy occurred due to community protests against the Sultan. According to the opposition, the Sultan's procedure was not under 


\section{Jurnal Ilmiah Al-Syir'ah Vol. 18, No. 2 (2020): 91-111 \\ Website: http://journal.iain-manado.ac.id/index.php/JIS ISSN 2528-0368 (online) ISSN 1693-4202 (print)}

Islamic Sharia. Eventually, all Land taken by the state was returned to its original owner. During the days of Sultan Salim I and Sulaiman I, the policy on the ground referred to the administration of Muhammad al-Fatih; the whole Land was returned to the state to increase the number of troops used for European conquest. And so on in $1528 \mathrm{AD}, 87 \%$ of the Land in the entire Ottoman Empire was al-Mirah (managed by the government). At the end of the 16th century A.D., the country lost much of this al-Mirah land (government land), which was one of the factors of the withdrawal of the Ottoman Empire in the economic, military, and political fields (Taneri, 2018).

The Timar system is fragmented because the state has Timar while the farmers have hereditary land management rights. Sipahi is Timar's owner and has part of the Land's rights because the Sipahi are called Sahib al-Ardh (landowner). However, he was only authorized to collect a certain amount of tax collected from land managers and hand it over to the state. The state guarantees its land rights to ensure the accommodation costs that it needs in daily life (Baskic1, 2005). Sipahi enjoys many facilities, and it is free to lease vacant Land to parties who are willing to work on it with rent that pays directly before the Land is cultivated. The farmers are committed to improving the area sustainably, but Sipahi has no right to change its function into fields, pastures, or gardens. If farmers no longer cultivate the Land for three years in a row, Sipahi can give other farmers Land. If someone lives in Timar's land area, then Sipahi collects sharia tax determined by the state. The state continues to print new lands by giving gifts and rewards to the Sipahi that add to the area of productive Land (Saharuddin et al., 2020). Sipahi gets a commission (Jufat) from the extra Land that it manages for her personal needs and the animals she cares for. The gift depends on the ground being ordered to start from 60-150 Daunam (1 Daunam $=2337.8$ square meters). Sometimes the Land is used for wineries or vegetables. Sipahi, who do not have children, cannot land their personal property because the Sipahi are obliged to give the Land to be managed by farmers. Based on this, Sipahi was a Timar collector who served only as a tax collector who applied state law on land management (Quataert, 1975).

Each head of the family takes his share of the Land (Jufat) to meet their daily needs but is no more than the family's needs. After he died, his family had the right to inherit it in managing the farmland. Because Jufat is a unit that cannot be divided, it is given to one household head. The "Jufat" is given according to the unity, area of the Land, and the results. In return for managing the Land, the farmers pay an annual tax service called Jufat Rasmi, which amounts to 22 Acke. This tax was initially funded by forced labor, which was valued at the price of straw, fodder, firewood, and other services provided by farmers to landlords during the Byzantine period. However, during the Ottoman era, this forced labor became more maximal and exchanged it with money as compensation for freeing farmers from this forced labor (Owen, 1993). 


\section{Jurnal Ilmiah Al-Syir'ah Vol. 18, No. 2 (2020): 91-111 \\ Website: http://journal.iain-manado.ac.id/index.php/JIS ISSN 2528-0368 (online) ISSN 1693-4202 (print)}

\section{Ra'ya and Timar}

$R a^{\prime} y a$; related to the Arabic word alraaei الراعي which means "shepherd, herdsman, patron" was a member of the tax-paying lower class of Ottoman society, in contrast to the askari (upper level) and $k u l$ (slaves). The rayah made up over $90 \%$ of the general population and the millet communities. In the Muslim world, rayah is the subject of a government or sovereign; the rayah (directly 'members of the flock') included Christians, Muslims, and Jews. They were 'shorn' (i.e., taxed) to support the state, and the associated 'professional Ottoman' class state gives servants the rights of the people to guarantee their income. In a general sense, the people consist of Muslims and non-Muslims. What is meant by the people here is a productive community working on agricultural Land. They pay taxes to countries whose positions are different from military groups. The narrow meaning of the people is a group of people who work on agricultural Land, a rural community whose role is different from the urban and nomadic communities. The Timar given to Sipahi is the land tax and tax on the individual farmers. In the 15th century A.D., the people were a fundamental element in agriculture because, at that time, productive agricultural Land was very extensive, which made the need for human resources increase as well. The limited number of farmers in villages and the size of agricultural Land has become a problem that extends between the Timar collectors (Özok-Gündoğan, 2015). They are competing to attract farmers to their respective fields. Farmers who run away from one of Sipahi's lands will make the Sipahi suffer losses; therefore, a law was held that prohibited farmers from moving soil. It is permissible for a Sipahi to withdraw farmers who have fled their area within 15 years, but this withdrawal must be based on a court decision. If there is a substitute for a farmer who runs away, then Sipahi can no longer pull the farmer who ran away to his Land again (Shah, 1967). If a farmer runs away from the area he manages and works in the city in a particular profession because he has the expertise, he must pay compensation for the Land he has left as much as one Ducat Gold in one year. However, farmers cannot be forced to return to the Land they leave behind (Quataert, 1994).

This situation began to change in the 16th century A.D.; the population of the Ottoman Empire snowballed in line with the expansion of productive agricultural Land. During Sulaiman al-Qanuni's agricultural land recording, land value increased according to the fertile lands' results. The new draft law was drafted and implemented after it became an official law that no longer allows farmers to leave their property. The bill also did not effectively prevent farmers from moving to the cities. As a solution, the government developed agricultural technology to anticipate farmers' migration to the cities (İnalc1k et al., 2006). Unlike in Western Europe, farmers cannot move from generation to generation and are not given a salary, only to be fed only with beans and pork. Hence, a mother sings in front of her baby. She hopes that the baby in her arms will die and not feel what her mother thinks because farmers in Europe are hereditary slaves who manage agricultural Land and do not get anything but food scraps and continuous forced labor (Barker, 2019). 


\section{Jurnal Ilmiah Al-Syir'ah Vol. 18, No. 2 (2020): 91-111 \\ Website: http://journal.iain-manado.ac.id/index.php/JIS ISSN 2528-0368 (online) ISSN 1693-4202 (print)}

The state gives Sipahi other rights in handling village security. Sipahi is entitled to get a fine paid by the village's occupation for the violations he made, both violations in civil and criminal matters. While the other half is paid to Sanjaq Beik (regional ruler), the judge can only determine this acceptable payment amount. Sipahi can imprison lawbreakers, but he cannot determine the number of fines to be paid by the offenders. Although Sipahi lives in the village where Timar was collected, he was not involved in agricultural land management, and he continued to carry out his military obligations. Sipahi livelihoods are regulated by law (Kanun Namah), which requires farmers to provide warehouses and move $1 / 10$ of agricultural produce to the warehouse if the distance is not more than one day's journey. Farmers must provide grass for the servants for horse food, but farmers are not obliged to bring dry grass to the storage warehouse. If the Sipahi comes to the village, the Sipahi has the right to get service for three days along with the horse he is driving. The law allows the servants to receive gifts on holidays in some areas, and in some areas, farmers are led to work for three days on Land controlled by the servants.

Kanun Namah (Sultan's law), which applies to each sanjak (region), varies in determining the tax amount. Sipahi cannot add other obligations to farmers. The Ottoman government is very concerned about the relationship between Sipahi and the people so that there is a separate article regulating the relationship. Sipahi, who do not comply with the law, will get a loss in the amount of Timar levies. Therefore, the Ottoman territory people got a better position than European people, far from the local authorities' arbitrariness. Farmers in the Ottoman provinces live under the protection of a central government with an independent legal system. However, in the 15th and 16th centuries A.D., cavalry soldiers and Beik (territorial rulers) abused their authority by trying to establish previous feudal customs. Farmers complain about the imposition of too high fines illegally (Meirison, 2017).

There are many complaints about the treatment of local authorities and judges who settled in their homes to maintain security and chase them. Therefore, farmers must provide food free of charge to the soldiers and provide food and care for their riding horses. Not only that, the servants who followed Sipahi, the regional authorities, and judges were also entertained while they were in the peasants' houses. Illegal levies also apply to increase the income of the servants, judges, and heads of this region. The rulers and leaders of this area no longer collect agricultural products in raw materials, but they oblige the collection of these taxes in the form of gold and silver coins. After Sultan Sulaiman Qanuni assumed power, the practices of extortion were abolished. In addition to this practice, it is detrimental to the people and detrimental to the state by reducing income to the country due to illegal levies and farmers' migration from one region to another, safer and more profitable. The Land will be neglected, the wretched rulers will only benefit for a moment, which will end with economic and social problems that are difficult to solve (Khoury, 1996).

Timar and lands owned by individuals bound most farmers in the Ottoman territories. But there are social distinctions from these strata of society. There is a 


\section{Jurnal Ilmiah Al-Syir'ah Vol. 18, No. 2 (2020): 91-111 \\ Website: http://journal.iain-manado.ac.id/index.php/JIS ISSN 2528-0368 (online) ISSN 1693-4202 (print)}

difference in the treatment and facilities between farmers who control Land in whole and part and the number of deposits they pay to the state. Their position in military service is also a consideration in facilities and services. While in the Balkans and Byzantine regions, there are farmers who are not recorded whether they control the Land or not; they are named Elephteroi (independent). During the Ottoman era, some farmers left their fields, and they worked as seasonal workers in the Timar region managed by Beik and Sipahi. If this seasonal farmer has been working on the Land for three years, then he has the right to control the Land for generations and enter the Timar system, which is managed by the Sipahi and Beik. In principle, the Ottoman Empire's government continued to try to keep farmers settled in a place to work productive agricultural Land for state income (Inalc1k et al., 2006).

There is another group of slaves and slaves who are similar to what prevails in Western Europe. They are only sharecroppers; they are prisoners of war or slaves bought and brought from one region to another. The Sultan's and state officials used them as private property or were part of the waqf property from mosques, schools, waqf agricultural land, the results of which were later used for the benefit of Muslims. State officials employ them on privately owned Land because they cannot get what they are working. All they get is just food and their family needs. However, they can still get the opportunity to free themselves because of Islamic Sharia that supports the freedom of slaves in the existing sanctions against violations of sharia made by a Muslim, including the slave owner himself (İnalc1k et al., 2006).

The state uses slaves and prisoners of war as rice farmers and others. They also worked as builders, construction workers, and fortresses, and weapons factories for military purposes. Sultan Muhammad al-Fatih placed slaves and captives in villages abandoned by their inhabitants when Constantinople's conquest occurred in 1453 AD. They worked as cultivating farmers they were prohibited from marrying other than their groups. They are required to deposit half of the agricultural produce they harvest from the Land they manage. In the 17th century, they joined ordinary people's ranks after undergoing various processes (İnalckk, 2016).

\section{Sipahi / Cavalry Army}

The Timar system's primary objective was to procure a military consisting of horseback riders and war equipment for the Sultan and, in other words, guarding and maintaining military personnel and equipment in large numbers under the control of the central government. Timar's leaders save horses, weapons such as arrows, javelins, swords, shields, spears piercing iron shields. If the tax collection results, they reach a certain amount, then he wears armor. Every three thousand Akçe, from his income, is used to prepare one soldier who is complete with his horse. At the same time, Beik makes a servant as compensation for 5000 Akçe he receives. From this, it can be concluded that Sipahi, which was produced in the 16th century A.D. from a tax of 9000 Akçe, went into battle with armor escorted by three horsemen. The more servants that are generated from the charge, the more prizes 


\section{Jurnal Ilmiah Al-Syir'ah Vol. 18, No. 2 (2020): 91-111 \\ Website: http://journal.iain-manado.ac.id/index.php/JIS ISSN 2528-0368 (online) ISSN 1693-4202 (print)}

will be obtained if the war is won. When the Sultan ordered prepare to fight, the servants gathered under the command of Subasyi under the banner of Sanjaks.

Meanwhile, the Beylerbey led the Sanjaks, who sometimes joined the Sultan's army. After that, the Sultan examined the troops accompanied by the prime minister and the regional commanders. Sipahi, who manages Timar, provides cavalry. One wing of the army worked on arranging the military to form a crescent formation to surround the enemy quickly. Troops-Timar's forces do not get a salary from the central treasury, and their horses will experience fatigue at the end of the summer. The prince returned to their post in early autumn. Therefore military activity began from March to October; that way, the Ottoman army was fragile in the fall. Therefore European military leaders know this like Janos Hunyadi. He attacks the Ottoman Empire continuously in the autumn of every year.

People get income from the Timar tax, consisting of layers of the military community. Giving Timar may not be given to ordinary people. A child can become a military member if his father or family comes from the military, Sultan's servants, or aristocrats (Aykan \& Ergene, 2019). The Ottoman Empire applied this system to the countries they conquered in Eastern and Central Europe. Eastern Europeans are slowly converting to Islam without coercion. They get a high income from the taxation of Timar. While you Muslims who get the results of this Timar is only Turks who were members of the elite Janisari forces in the 15-16th century A.D., or the slaves used as soldiers came from the children of the conquest. There is a note in $1431 \mathrm{AD}$ about the border region in Albania that $16 \%$ of the cavalrymen who got results from Timar were Christians, 30\% consisted of Turks, and 50\% consisted of the Sultan's slaves and Beik (head of the region). While the remaining 4\% was distributed to the judges (qadi), scholars, and people close to the Sultan. (Birken, 1976) With the increasing number of Turkish servants, children inherit the father in getting a similar Timar. If a prisoner gets 10-20 thousand Akçe, the oldest child gets 4000 Akçe, and the second gets 3000 Akçe. If the number of dead men is Timar, it ranges between 20-50 thousand Akçe. If Sipahi has a child, the first three will inherit 6000 Akçe, then the other 5000 Akçe, the third Timar 4000 Akçe. But unlike the Western European feudal system because hereditary inheritance is not absolute. If a prisoner does not fulfill his military obligations for seven years in a row, he will lose his position as a servant, and his name will be included in the list of ordinary people who must pay taxes. If the civil servants whose rights have been revoked take part in war or other military services, then the rights will be returned following the commander's recommendation within seven years. Connoisseurs of Timar have a big difference in the amount they receive. The Beik he received the Timar directly from the palace ranged from 600,000 - 1000,000 Akçe in the range the number was named (typical). Sanjaq (regional head) ranges from 200,000 - 600,000 Akçe while Subasi (police chief), 20,000 - 100,000 Akçe. Sipahi, the manager of Timar, his income, including the middle class in the 15th century A.D., reached 2000 Akçe; in the 16th century, it increased to 3000 Akçe.

The continuing need to add Timar has pushed the country to conquer new territories. Qabi Quli troops (elite troops) always want war because of Timar's 


\section{Jurnal Ilmiah Al-Syir'ah Vol. 18, No. 2 (2020): 91-111 \\ Website: http://journal.iain-manado.ac.id/index.php/JIS ISSN 2528-0368 (online) ISSN 1693-4202 (print)}

number; zi $^{\prime} a m a t^{1}$ will be shared with those who succeed in their mission and exert tremendous courage on the battlefield. Timar's need is increasingly high; the expansion of territory continues to run, sometimes without control. There was an unhealthy competition between the Turkish volunteer troops from Anatolia, the border guards who always demanded Timar, and the servants who managed the Timar. Tension has given us an idea of why the border forces in the Balkans in the middle of the 14th century A.D. were always disloyal, who sometimes sided with the enemy. The dispute continued with problems between the servants in the Anatolian provinces and the new Ottoman Turkish military administration system. The Sultan has revoked non-compliant servants' rights to carry out their duties for seven consecutive years with new servants (Mantran \& Bacqué-Grammont, 2003). There was a dispute between the local Sipahi and the new Sipahi that had been raised by the Sultan. The domestic servants had carried out rebellions in Izmir and Sharukhan in 1416 AD and Karaman in 1468-1511 AD. The deprived servants had gathered with the poor servants and those. The latter demanded that Timar gathers with the rebellious royal family; Timar is a limited state revenue and cannot meet overall operational funding. In $1528 \mathrm{AD}$, the Ottoman Empire's total income recorded 9,650,000 Billion Ducat gold, of which 37\% of the total revenue came from Timar. 50\% of this total income is deposited to the Sultan or the state treasury. The remainder of this income was generated from the Khawas Sultan, then from the excise tax paid by traders in the cities, income from gold, silver, copper, and coal mines. Jizyah is paid by non-Muslims collected by central officers only. This jizyah was delivered in 1525 AD in the amount of 750,000 Ducat gold. The Sultan distributed this income to Janissari members and al-Qabi Quli forces, who were accustomed to receiving salaries in the form of gold coins. The reception's remainder was paid to the fort guards, the palace's needs, and public facilities (Finkel, 1988).

There was an abuse of Timar, and he was not only paid to military groups but also to palace officials and government officials, both active and retired. Government officials, eunuch guards (castrated guards) also get this Timar ration to destroy the Timar system. The army's management is disrupted by administration and finances (İnalc1k et al., 2006).

\section{Administration and Timar System}

The Timar system is like an administrative institution, starting from Beylerbey to Sipahi, which is an executive institution under the authority of the Sultan in the regions. Sipahi has several administrative tasks that she must carry out. Private duties such as the police who maintain security in the countryside, collect taxes, apply laws related to agricultural Land. Beylerbey heads the territories, which are the Sultan's representatives in each region. Beylerbey, in essential areas such as Egypt, has an equal position with ministers who have

\footnotetext{
${ }^{1} \mathrm{Zi}$ 'amat is a level of land management that generates more quantities from Timar.
} 


\section{Jurnal Ilmiah Al-Syir'ah Vol. 18, No. 2 (2020): 91-111 \\ Website: http://journal.iain-manado.ac.id/index.php/JIS ISSN 2528-0368 (online) ISSN 1693-4202 (print)}

executive authority, such as dismissing judges and deciding the death penalty (Inalcik, 1969).

Under Beylerbey's leadership, financial and regional treasury officials handled the Timar case, and the treasurer dealt with other income issues directly related to the country's treasury in the capital. Both treasuries have their own offices and administrations. The existing treasury system in the regions constitutes the central treasury and governance model. Beylerbey has a deputy secretary who conducts the correspondent. The Beik Administration handles cases related to Timar, a lawsuit between the Sipahi and the people. In an emergency, the judge also discussed an urgent matter with this institution. Several Subasyi manages Land that produces abundant harvests of privately owned/non-Timar (Typical), under the control of Bakoler Beik as in Egypt. Likewise, with the grounds of Timar, which are controlled by the military. This was done to expand Beylerbey's authority and prevent one group from dominating these agricultural lands (Uzunçarşıl1, 1988).

\section{Legal and Financial Administration}

The Ottoman territories are further divided into legal and judicial administration. Judges or qadis live in cities, and they send their representatives to all regions and remote areas. The judges apply the shari'a and qanun (law), but at the same time, he has the right to use the Sultan's regulations in financial management. That way, the judge also functions as a financial regulator and supervisor. The judge will always check the finances regularly. In the event of irregularities, the judge will report it to the central government or resolve the case if possible (Tezcan, 2009).

The judges were the backbone of the Ottoman Turks' administration, so in the 15th century A.D., a judge could have occupied the position of Sanjaks Beik (regional leader) or Beylerbey. However, there is an abuse of the status of qadi / judge given to them. The state has limited the number of judges. Therefore many are trying to achieve this position in any way as many want the results from Timar. However, they never functioned as workers, land managers, or military officers who worked in the villages (Rari, 2001). Those who have ambitions are willing to wait for this position indefinitely or indefinitely. Because when they get this position, they will get rich suddenly in a short time. After that, the judge's opinion was given to someone for only one year.

In the mid-16th century A.D., there were hundreds of madrassas in Anatolia to educate these prospective judges who had become a significant burden on the Ottoman Empire. They have become a mafia group that makes life insecure chaotic in the cities, and robbing in the villages (İnalc1k et al., 2006). The third pillar is the State Treasury Register, which regulates the benefit of state finances both in the central government and in the regions. Pera financial officials can determine policies independently as a judge (Meirion, 2019a). The fiscal officer can deal directly with the capital and instantly report the regional head's treatment and conduct to the Sultan. Instead, the provincial leader can dismiss judges and financial 


\section{Jurnal Ilmiah Al-Syir'ah Vol. 18, No. 2 (2020): 91-111 \\ Website: http://journal.iain-manado.ac.id/index.php/JIS ISSN 2528-0368 (online) ISSN 1693-4202 (print)}

officials if there are mistakes and violations committed by them with substantial evidence. However, this case must be reported to the capital quickly (Tezcan, 2009).

\section{Analysis of The Timar System}

Although many experienced changes in the Timar system related to financial administration and Land, this is still based on land productivity and workers who want to work on it without coercion and pressure voluntarily. Islam comes with shari'ah giving humans the maximum benefit in exploiting the crops and utilizing natural resources to the full. Islam allows productive age groups to raise their spirits in farming. They are not placed as mere workers and landowners, which is meant by reviving the property if someone intentionally manages the Land to be planted and does not belong to someone else. He rinses and cultivates it or builds it, and then the area is legitimately his property. The Prophet Muhammad PBUH confirmed the old way of ownership in the Land according to humanity's nature. Exploiting the earth is by building and reconstructing area, by planting it based on the words of Allah Almighty:

And a sign for them is the dead earth. We live the ground, and we remove the grain from it so that they can eat it (Q.S. Yasin: 33)

God explained that He had revived the soil and cultivated the seeds that later became human consumption crops. Still, humans undermined this process in modern times due to genetically engineered patent rights that can only grow once and for all humans. Who ate it is unknown until now. The Hadith of the Prophet PBUH has encouraged his people to build and reconstruct the Land; he says: (1) Whoever develops/revives a dead area that is not owned by another person is entitled to that Land (Bukhārī \& Nașșār, 2009); (2) Whoever revives the numb area belongs to him (Bukhārī \& Nașșār, 2009); (3) Whoever fences (makes gardens) the Land belongs to him (Sa'īè̄, 2006$)$; (4) Whoever has previously claimed (Land) that a Muslim meal has not been preceded will be his (Sa'īìī, 2006).

All of the above hadiths show the importance of developing the Land's potential by supporting the person who will develop it following the human nature of love for ownership. With the prospect of owning a piece of ground or more farmers or people who will revive their dead area, they will be more motivated in their efforts. In this way, the unemployed group of productive workers can be empowered not as workers but as owners. The food industry sector can be expanded; the natural resources that were once abandoned to be productive and livelihood of society will eventually bring a country to the food industry's endurance and prosperity and end with absolute food security. The difference between the land administration system during the time of the Messenger of Allah and his Companions was in farmers' and landowners' contribution to military equipment and military personnel's procurement during the very long period.

Although there have been many changes, land management, in principle, is not subject to a substantial land tax as applicable in Western Europe. Peasants are 


\section{Jurnal Ilmiah Al-Syir'ah Vol. 18, No. 2 (2020): 91-111 \\ Website: http://journal.iain-manado.ac.id/index.php/JIS ISSN 2528-0368 (online) ISSN 1693-4202 (print)}

not seen as slaves tied to agricultural Land so that farmers can move to another area or move to live in the city with their children and wives, and descendants. This does not apply in Europe, farmers are taken from Africa, and they are employed on plantation land. The psychological impact is evident until now that black people are not considered human beings who must be respected for their dignity. With this system, the Ottoman Turks have survived hundreds of years in food security, supporting the people's economy and mostly military power.

Indonesia has always experienced food shortages from time to time since the Raffles era (1811 - 11 March 1816). The Dutch government imports food to Indonesia for workers who are urgently needed to grow spices and other commodities that are badly needed in Western Europe. During the Soekarno Period, Land Reform also attempted to give Land to the peasants who would use it as did the Ottoman Turks for centuries. However, Sukarno's Land Reform efforts failed because they were not strong enough to press the political parties whose leaders were in parliament in Jakarta. These political party leaders are not willing to have their abandoned Land managed by poor farmers. So that during the Soekarno, there was hunger everywhere. Sukarno turned the Indonesian people's attention to the conflict with Malaysia so that it was hoped that the community would forget about the problem of food shortages. After that, there was a prolonged economic crisis.

Historically, the Orde Lama had placed land reforms as a revolutionary policy in development by issuing land redistribution regulations according to Law No.56 of the 1960 Prp. Imperialism, feudalism, and capitalism carried out land reforms according to Indonesian national law provisions while laying the foundations for industrialization, the whole and heavy industry that must be cultivated and controlled by the state. RI MPRS TAP Number II/MPRS /1960 and the Political Manifesto mentioned three philosophical foundations of development at this time, namely: anti-exploitation of humans by human economic independence; and anti-colonialism, imperialism, feudalism, and capitalism with land reform as the main list so that it can say that the land reform program as the initial implementation of these objectives, in its performance failed, that's because: (1) The inaction of government practices in the performance of the State's Right to Control; (2) The demands of the organization and mass of farmers who want to redistribute Land immediately so that unilateral action arises; (3) Anti-land reform elements that carry out various mobilizations of fighting forces and tactics to avoid and to frustrate land reforms; (4) The involvement of violence between the two parties, who supports and who opposes.

Despite obtaining Land, some farmers still pay land tax according to Dutch regulations. This land tax is different from what is implemented by the Ottoman Empire's agricultural land administration system adopted from Islamic Sharia. In Islam, according to which no results are not required to surrender any of the Land used, or the results do not reach Nisab as zakat payment. However, the West's law, in particular, Britain, focused on the property, not on the area's products. At the same time, Islam supports farmers to keep working with the lure of productive land ownership to raise food security. The Ottoman Empire, which has existed for 


\section{Jurnal Ilmiah Al-Syir'ah Vol. 18, No. 2 (2020): 91-111 \\ Website: http://journal.iain-manado.ac.id/index.php/JIS ISSN 2528-0368 (online) ISSN 1693-4202 (print)}

hundreds of years, has never, significant food shortages, can even help the famine that occurred in Ireland in 1845, where Queen Victoria did not show her responsibility by letting Irish people starve to death (Ó'Gráda, 1995).

\section{CONCLUSION}

The Timar system's loss made it increasingly difficult for the Ottoman government to procure military personnel and equipment that were, in fact, in harmony with the central government's control of the region with the presence of Janissary. Timar's absence made Janissari more flexible and became the little kings in the areas that caused the financial administration system to no more extended function correctly. Janissary is useful to limit the regional authority held by Beylerbey, Subasyi, along with the judges and economic officials. The barracks (elite soldiers) help deal with enemies from outside and within the country. They also function as security officers in riots between Muslims and Christians in the Ottoman Empire. Janissaries are responsible for the security of ambassadors, routes, and trade activities over Land and sea. However, in the absence of Timar, it did not function properly. Although it has changed from the financial administration and land systems in Islam, the Ottoman Empire still holds the jurists' opinions. The authorities handed over the Land to the people who would manage it without being burdened with routine taxes. This situation has sustained the food security of the Ottoman Empire for hundreds of years.

This elite army's barracks continued to grow in cities and towns in each region in the 16th century C.E. The chaos was more frequent at that time. With the weakening of the central government's influence caused by the leadership crisis, the transfer of power to the military barracks in these areas such as in Algeria, Egypt, Libya, Baghdad, and the Hijaz region (now Saudi Arabia). These elite armies also formed their hierarchy in these areas.

This principle in Islam was once applied during the Soekarno period called Landreform but failed because landowners are unwilling to use their Land by farmers. Bung Karno's power and political charisma were unable to solve the problem. During the Soeharto era, the transmigration program was half-hearted. Food yields rise and achieve food security, but farmers' incomes do not increaseexpensive production costs due to collaboration with large cartels from the United States. Farmers lose the expected income even though these costs were assisted by the New Order government doing their business as the Green Revolution, which has destroyed Land and ensnared the farmers.

\section{ACKNOWLEDGMENTS}

Praise be to Allah, Lord of Universe, there is no God but Allah, thanks to Almighty God. The author thanks the late Ir. Alizar Sali, Ir. Marwan Nasution, Ir. Husein Harahap LLM, as officials of Indonesian Government Food Agency, have helped provide enlightenment on food security and other resource persons as Indonesian field officers Government food Agency. The author thanks Prof. Dr. 


\section{Jurnal Ilmiah Al-Syir'ah Vol. 18, No. 2 (2020): 91-111 \\ Website: http://journal.iain-manado.ac.id/index.php/JIS ISSN 2528-0368 (online) ISSN 1693-4202 (print)}

H.M Atho Mudzhar MSPD, Dr. Mawardi Lc, MA, who has examined research proposals on food security in Islamic Point of Views who contributed to the preparation of this article. I would also like to gratefully thank Prof. Dr. Alaiddin Koto M.A, who has provided direction in the discussion of food security in Islam.

\section{REFERENCES}

Aykan, Y., \& Ergene, B. (2019). Shari'a Courts in the Ottoman Empire Before the Tanzimat. The Medieval History Journal, 22(2), 203-228. https://doi.org/10.1177/0971945819897437

Barker, H. (2019). Slavery in Medieval Europe. In Medieval Studies. Oxford University Press.

Barkey, K., \& Gavrilis, G. (2016). The Ottoman Millet System: Non-Territorial Autonomy and its Contemporary Legacy. Ethnopolitics, 15(1), 24-42. https://doi.org/10.1080/17449057.2015.1101845

Baskıcı, M. M. (2005). 1800-1914 yıllarında Anadolu'da iktisadi değişim. Turhan Kitabevi.

Birken, A. (1976). Die Provinzen des Osmanischen Reiches (1. Aufl). Reichert.

Bukhārī, M. ibn I., \& Nașṣār, M. M. M. Ḥasan. (2009). دار الكتب العلمية .صحيح البخاري:

Farid Bek Al-Muhami, M. (2009). Tarij al-dawla al-'aliyya al-'utmaniyya. Dar alNafa' is.

Finkel, C. (1988). The Administration of Warfare: The Ottoman Military Campaigns in Hungary, 1593-1606. VWGÖ.

Halim, A. (1987). Tarikh Al-Qadha Fi Daulah Usmaniyah (Vol. 1). Dar Al-Kutub Al-Ilmiyah.

Inalcik, H. (1969). The Policy of Mehmed II toward the Greek Population of Istanbul and the Byzantine Buildings of the City. Dumbarton Oaks Papers, 23, 229. https://doi.org/10.2307/1291293

İnalcık, H. (2016). Osmanlı'da devlet, hukuk ve adâlet.

İnalc1k, H., \& İnalc1k, H. (2014). Klasik dönem (1302-1606), siyasal, kurumsal ve ekonomik gelişim (53. basım). Türkiye İş Bankası Kültür Yayınları.

İnalcık, H., Quataert, D., Berktay, H., Eren, M. S., Faroqhi, S., McGowan, B. W., Quataert, D., \& Pamuk, Ş. (2006). Osmanlı Imparatorluğu'nun ekonomik ve sosyal tarihi.

İslamoğlu-İnan, H., ed. (2004). The Ottoman Empire and the world-economy (1st pbk. ed). Cambridge University Press.

Issawi, C. P., ed. (1980). The Economic history of Turkey, 1800-1914. University of Chicago Press.

Khoury, D. R. (1996). Halil Inalcik and Donald Quataert, ed., An Economic and Social History of the Ottoman Empire, 1300-1914 (New York: Cambridge

Administration And Finance System of the Ottoman Empire 


\section{Jurnal Ilmiah Al-Syir'ah Vol. 18, No. 2 (2020): 91-111 \\ Website: http://journal.iain-manado.ac.id/index.php/JIS ISSN 2528-0368 (online) ISSN 1693-4202 (print)}

University Press, 1994). Pp. 1,057. International Journal of Middle East Studies, 28(2), 289-291. https://doi.org/10.1017/S0020743800063376

Mantran, R., \& Bacqué-Grammont, J.-L., eds. (2003). Histoire de l'empire Ottoman. Fayard.

Meirison, M. (2017). Al-Fiqh Al-Islāmiy wa Āsāaruhu 'alā al-Qānūn al-Ūrūbiy. Journal of Islamic Studies and Humanities, 2(Desember), 193-217. https://doi.org/http://dx.doi.org/10.21580/jish.22.2524

Meirison, M. (2019a). Legal Drafting in the Ottoman Period. Jurnal Ilmiah AlSyir'ah, 17(1), 39. https://doi.org/10.30984/jis.v17i1.806

Meirison, M. (2019b). Sejarah Kepemimpinan Wanita di Timur Tengah Dalam Tinjauan Hukum Islam (Analisa Terhadap Syajar al Durr). Kafa ah: Journal of Gender Studies, 9(1), 50. https://doi.org/10.15548/jk.v9i1.231

Ó’Gráda, C. (1995). The Great Irish Famine (1st ed.). Cambridge University Press.

Owen, R. (1993). The Middle East in the world economy, 1800-1914 (Rev. pbk. ed). I.B. Tauris.

Özok-Gündoğan, N. (2015). Ottoman Empire. In N. Dalziel \& J. M. MacKenzie (Eds.), The Encyclopedia of Empire (pp. 1-14). John Wiley \& Sons, Ltd.

Pamuk, S.. (2004). Prices in the Ottoman Empire, 1469-1914. International Journal of Middle East Studies, 36(3), 451-468.

Pamuk, SS. (2010). The Ottoman Empire and European capitalism, 1820 - 1913: trade, investment and production (Dig. print. vers. 2010). Cambridge Univ. Press.

Quataert, D. (1975). Dilemma of Development: The Agricultural Bank and Agricultural Reform in Ottoman Turkey, 1888-1908. International Journal of Middle East Studies, 6(2), 210-227. https://doi.org/10.1017/S002074380002451X

Quataert, D., ed. (1994). Manufacturing in the Ottoman Empire and Turkey, 15001950. State University of New York Press.

Rari, I. (2001). Imparatorlugun Turkcede (Vol. 1). Alkim Yayinevi.

Saharuddin, D., Meirison, M., Chusna, I., \& Mulazid, A. S. (2020). Capitulation and Siyasah Syar'iyah Al-Maliyah Impact on Economic Stability of the 18th \& 19th Ottoman Turks. QIJIS (Qudus International Journal of Islamic Studies), 7(2), 329. https://doi.org/10.21043/qijis.v7i2.4847

Sa'īdī', 'Umar Fārūqī. (2006). Sunan Abū Dā'ūd. Dārulislām.

Shah, R. (1967). Açi Padisahı Sultan Alaeddin'in Kanuni Sultan Süleyman'a Mektubu" [The letter of Aceh Sultan Alaaddin to Sultan Suleyman the Magnificent]. Ankara Üniversitesi Dil, Tarih-Cografya Fakültesi Tarih Arastırmalarl Dejrgisi [The Journal of History Researches of Ankara University, Faculty of Language, History and Geography], 5, 373-409. 
Jurnal Ilmiah Al-Syir'ah Vol. 18, No. 2 (2020): 91-111

Website: http://journal.iain-manado.ac.id/index.php/JIS

ISSN 2528-0368 (online) ISSN 1693-4202 (print)

Taneri, A. (2018). Osmanlı Devleti’nin Kuruluş Döneminde Hükümdarlık Kurumunun Gelişmesi ve Saray Hayatı.

Taskinsoy, J. (2019). Turkey's Unravelling Economy Resembles the Ottoman Empire's Financial Collapse. SSRN Electronic Journal. https://doi.org/10.2139/ssrn.3461216

Tezcan, B. (2009). The Ottoman Monetary Crisis of 1585 Revisited. Journal of the Economic and Social History of the Orient, 52(3), 460-504.

Uzunçarşı1lı, İ. H. (1988). Osmanlı devletinin ilmiye teşkilâtı (3. Baskı). Türk Tarih Kurumu Basimevi. 